INDEPENDENT JOURNAL OF MANAGEMENT \& PRODUCTION (IJM\&P)

http://www.ijmp.jor.br

v. 11, n. 6, September - October 2020

ISSN: 2236-269X

DOI: 10.14807/ijmp.v11i6.1209

\title{
INTEGRATED MATHEMATICAL MODEL BASED ON A HEURISTIC METHOD FOR LOADING AND ROUTING OF VEHICLES: APPLICATION IN A TOBACCO COMPANY
}

\author{
Jorge Israel Frómeta Moya \\ University of Oriente (UO), Cuba \\ E-mail: jorgef@uo.edu.cu \\ Daniel René Tasé Velázquez \\ Methodist University of Piracicaba (UNIMEP), Brazil \\ E-mail:dtasev88@gmail.com \\ Lorena Hernández Mastrapa \\ Methodist University of Piracicaba (UNIMEP), Brazil \\ E-mail: lorenahmastrapa@gmail.com \\ Yosvany Orlando Lao León \\ University of Holguín (UHO), Cuba \\ E-mail: ylaol1986@gmail.com
}

Submission: $12 / 18 / 2019$

Accept: 01/07/2020

\section{ABSTRACT}

The vehicle-routing problem (VRP) combined with freight-loading problem is a complex and relatively recent issue studied by the scientific literature. This paper presents the formulation of a mathematical model and a procedure to solve this problem in a Cuban tobacco company aiming to determine the quantity of merchandise to be loaded on vehicles and the best route to be taken. For this purpose, a decomposition's heuristic method was used and it was integrated with multiobjective programming by-goals and mixed binary quadratic programming. This approach allowed simplifying the problem and offering a satisfactory solution based on the demand fulfillment, the vehicles' rational use and for searching the local optimums of the traffic load indicator. The model was tested in a case study and its feasibility evaluated based on a real operational situation in a tobacco company. Although the results of the application of the developed model does not imply reaching the optimal solution to the problem studied, it represents an opportunity for company's performance improvement and it could be adapted and applied to other institutions dedicated to the same activities. 
DOI: 10.14807/ijmp.v11i6.1209

Keywords: Vehicle-routing problem; Freight-loading problem; Heuristic methods; Goalsbased programming; Quadratic programming

\section{INTRODUCTION}

The vehicle-routing problem (VRP) has been extensively investigated over more than 50 years, from the approach of the "Traveling Salesman Problem" (TSP) (DANTZIG et al., 1954). The VRP is an important issue and recent studies have being developed. Smiti et al. (2020) studied the Cumulative Capable Vehicle Routing Problem (CCVRP), that is a relatively new version of the classic CVRP and is equivalent to a capacity constrained itinerant repairer problem and a homogeneous vehicle fleet, which aims to minimize the total uptime arrival to customers.

In previous literature review (MASTRAPA et al., 2018a), it was identified that in cases of emergency (humanitarian logistics), the VRP is mostly focused on minimizing the sum of arrival times. One the biggest challenge is responding to the demand (any kind) with minimal operating costs in addition to social costs, as in humanitarian logistics the main goal is to provide the highest service level in the shortest time possible, which often require very high operating and social costs.

However, the study of the approach that integrates the VRP with vehicles freight loading is more recent (BORTFELDT; WÄSCHER, 2013; IORI; MARTELLO, 2016). The objective of this approach aims to find the best vehicle routing programming, given the constraints that impose the limited capacity of the vehicles regarding the merchandise to be loaded. In these cases, the tools contemplated within the Operational Research discipline have been fundamental, as part of the mathematical modeling of these problems for their solution (MEDINA et al. 2011).

Most of the cases that integrate these two approaches belongs to the kind of problems with solutions that present strongly undetermined polynomial time (strongly NP-hard), so they are a challenge for achieving an optimal solution (IORI; MARTELLO, 2016). This is the case of the VRP, which is well-known as an NP-hard problem (PIQUERAS, 2002; LÜER et al., 2009; MEDINA et al. 2011; CHOWMALI; SUKTO, 2020), and it is a famous problem in operations research and combinatorial optimization (CHOKANAT et al., 2019; WICHAPA; KHOKHAJAIKIAT, 2018). The vehicles freight distribution problem with loading constraints is also considered as NP-hard problem (PACE et al., 2015). That is why it is not feasible to 


\section{INDEPENDENT JOURNAL OF MANAGEMENT \& PRODUCTION (IJM\&P)}

http://www.ijmp.jor.br

v. 11, n. 6, September - October 2020

ISSN: 2236-269X

DOI: 10.14807/ijmp.v11i6.1209

search for exact mathematical methods to solve these problems, although the use of such methods is not ruled out (IORI; MARTELLO, 2016).

Some alternatives were proposed for solving these combined problems. One of them includes the approach of Tarantilis et al. (2009). They used up to six heuristics to solve the VPR with Simultaneous Pick-ups and Deliveries and Two-Dimensional Loading Constraints (2L-SPD), primarily to reduce the computational cost involved in this kind of complex mathematical models, and find the optimal solutions in reasonable times. However, the methodology used did not allow a deeper study of the operational objectives related to a problem of this type, restricting the modeling to a single objective for this approach, due to its multidimensional nature, it could be more flexible.

Fuellerer et al. (2009) used the ant colony metaheuristics method for solving a Logistics distribution problem classified as Vehicle Routing Problem and Two-Dimensional Loading Constraints (2L-VRP). These authors demonstrated that the use of this technique allows the successful combination of two approaches with completely different measurement criteria, being superior to other algorithms studied (IORI; MARTELLO, 2016). However, the methodology used lacks a more targeted approach to the decision-making process, perhaps due to the very nature and complexity of the metaheuristic method used.

Duhamel et al (2010) made another interesting proposal as they used heuristics decomposition for routing as well as metaheuristics for designing a set of trips minimizing the total transportation cost with a homogenous fleet of vehicles based on a depot node, as a solution of a Capacitated Vehicle Routing Problem and Two-Dimensional Loading Constraints (2L-CVRP). These authors demonstrated that the use of this approach implies a high efficiency for solving this kind of problems, and presents a better computational performance compared to other algorithms compared in their research. However, the methodology used lacks a completely comprehensive approach to a problem of a composite nature, giving greater attention on solving the CVRP and Two-Dimensional Loading Problem in a separately manner, rather than in its integrated configuration, and the approaches that emerge from that interrelation.

Corstjens et al. (2020) propose a statistical methodology to understand the performance of an heuristic algorithm to investigate the correlations between algorithm performance and algorithm parameters and correlations between the latter and the instance characteristics of the problem. They see this as a next step in experimental research on combinatorial optimization 
DOI: 10.14807/ijmp.v11i6.1209

problems to gain a deeper understanding and insight into the effects of heuristic parameters and components on algorithm performance. The methodology is able to identify which algorithm parameters significantly affect the solution quality of a heuristic method and how the characteristics of the problem instance influence these effects. However, the current methodology considers single-goal optimization, but optimization problems, such as vehicle routing, typically consider multiple objectives.

Mastrapa (2017) and Mastrapa et al. (2018b) in their study addresses the Problem of Design of Urban Public Transport Networks (PDRTPU). They focused on the improvement of a heuristic algorithm based on minimum path methods aiming to obtain a solution that meets the users demand, minimizing the number of transshipments, with a significantly smaller number of lines than the one found in the original application of Aquino (1980).

Chowmali and Sukto (2020) investigated a solution method for the cluster-based multicompartment vehicle routing problem (MCVRP) in which a variant of FJA (Fisher and Jaikumar algorithm) was considered to cluster the nodes, and the TSP model was employed to find the ideal routes of individual vehicles. The numerical results showed the effectiveness of the proposed heuristic. They recomended as further research, the application of the proposed heuristic to be tested with more cases of MCVRP to further increase the validity of the search results.

Tobacco companies in the eastern region of Cuba find vehicular routing combined with the freight loading among their most pressing problems in their logistics management. Currently, a company in that branch is looking forward a new way to improve the physical distribution of their merchandise, specifically, physical distribution of raw material; among the various problems they have had, it is included:

- Failure to meet delivery deadlines of raw material: There has been a production delay of hand-twisted tobacco due to insufficient delivery of raw material to the Production Base, despite being stocked in the Company warehouses;

- Absence of a methodological planning tool for physical distribution: The collaborator in charge of the physical distribution planning process does not use methodological tools (computational software, mathematical algorithms, etc.), but instead performs it empirically, without taking full account about aspects such as the travel distance, the vehicle capacity constraints, freight-loading and unloading volume, etc. 
DOI: 10.14807/ijmp.v11i6.1209

Therefore, the aim of this paper is to propose an integrated mathematical model for freight loading and vehicle routing as a tool to improve the process of physical distribution of raw materials in a Cuban tobacco company. The proposed methodology in this paper based on a heuristic algorithm can be framed within the "tailored algorithms" classification, as it is designed for a very specific situation. This gives it the advantage of greater flexibility in modeling the characteristics of a problem that are not incorporated in the theoretical schemes of the reviewed literature, such as the use of the load traffic indicator for objectives modeling; or consideration in the freight sub problem of both volume and weight restrictions.

In addition, regarding the other approaches analyzed in the literature, the algorithm configured for the method proposed have a lower focus on the computational cost of the proposal and greater focus on the decision-making process within the problem described. This presents an advantage in practical terms for implementation and development of the proposal over others in literature, for specific problems such as the studied in this paper.

This work is organized in fourth sections. The introduction, which contextualize and presents the paper research interest and main objective; the methodology is discussed in the next section; results and discussion, as the third one, includes the structured model flow and the procedure configured, main data used and main results on the research context; and final considerations as conclusions are settled at the last one.

\section{METHODOLOGY}

The main stages for the implementation of operational research principles for the resolution of a problem can be summarized as follow (HILLIER; LIEBERMAN, 2004; ORTIZ-TRIANA; CAICEDO-ROLÓN, 2014): (i) the problem definition; (ii) the model configuration; (iii) the model's solution; (iv) the model's validation, and; (v) the implementation of the solution.

In this paper is used this procedure, specifically the first four stages, as a methodological guide in order to fulfill the objective proposed. For configuring the model, a heuristic method of decomposition of the problem with cascade solution is used, which is based on the principle “divide and conquer”. This principle allows fragmenting the problem into smaller ones, so, when solving them all, a solution is obtained for the global problem (PIQUERAS, 2002).

The solution of some sub-problems constitutes relevant data of the following ones. This approach is combined with multi-objective programming by-goals for vehicles freight loading and with an exact method of optimization named mixed binary quadratic programming of 
DOI: 10.14807/ijmp.v11i6.1209

vehicle routes by stages, as well as, linking algorithms between the different stages as the problem is divided.

The problem of mixed binary quadratic programming modeled according to its standard form contains a quadratic objective function and linear constraints (NGUYEN et al., 2016). The traffic load indicator is used as a solution criteria, which is "the magnitude of the work in the freight's transport combining the freight and the distance which the products and goods are transported" (ONEI, 2015). Although this is one of the most difficult problems in combinatorial optimization, usually with solutions in undetermined polynomial time (NP-hard) (BURKARD et al., 2012), some cases are relatively simple (ADAMS; WADDELL, 2014; LAURENT; SEMINAROTI, 2015). The case study of this paper is one of them.

\section{RESULTS AND DISCUSSIONS}

In this section are presented the results obtained after the implementation of the four stages defined in previous section for solving the problem studied.

\section{Stage I. Problem's definition}

The problem is defined as follow: Insufficiencies of the physical distribution of raw materials process in a tobacco company that affect the efficiency and effectiveness of the operational (production) process.

The precepts that serve as the basis for the mathematical model configuration were established as follows:

- There is only one origin, with availability of the products demanded by the destinations, this availability is known at all times;

- There are destinations whose demand for goods is known;

- There are vehicles (one fleet), heterogeneous, limited and with constrained capacity;

- There are no established priorities between destinations or between goods;

- The capacities of the vehicles are known based on the goods' characteristics;

- Within the cost system, the unit transportation costs (variable or fixed) are not identified, and they are assumed proportional to the distance traveled, and independent of the type of vehicle or destination;

- There are no time constraints;

- It is considered that in all destinations the merchandise will be accepted (no returns are contemplated). 


\section{Stage II. Mathematical model configuration}

The formulated mathematical model and the procedure for solving the problems studied imply the development and application of a heuristic method of decomposition. The flow chart that summarizes the algorithm that supports the model is shown in Figure 1.

The following guidelines were settled for configuring the mathematical model:

\section{Model subscripts definition}

Stages (n): Ordinal identification of the subproblems sequence in chronological order about the freight to be loaded and distributed by the vehicles, and the programming of each vehicle's visit to the destinations as part of the distribution's vehicular routing $(\mathrm{n}=1,2, \ldots, N)$.

$i$ : Nominal identification of the vehicles available for distribution $(i=1,2, \ldots, I)$.

$j$ : Nominal identification of destinations with demand for goods $(j=1,2, \ldots, J)$.

$k$ : Nominal identification of the goods to be distributed $(k=1,2, \ldots, K)$.

\section{Model Parameters}

$I_{k}$ : Availability of merchandise $k$ in the warehouse (origin) at the beginning of the problem.

$D_{j k}$ : Demand for merchandise $k$ at destination $j$ at the beginning of the problem.

$c_{i k}$ : Capacity coefficient of the merchandise $k$ in the vehicle $i$ regardless of the stage in which it is located.

$d_{p_{i_{n}} p_{j}}$ : Distance traveled by the vehicle $i$ to the destination $j$.

$w_{k}$ : Weight of each unit of merchandise $k$ expressed in kilograms $(\mathrm{kg})$.

$p_{j}$ : Physical position of the destinations within the independent model of the Stage (1, $2 \ldots, P) / p_{j}=j$.

$p_{i_{n}}$ : Physical position of the vehicle $i$ in Stage $n$ within the model $(0,1,2 \ldots, P) / 0=$ physical position of the warehouse.

\section{Definition of model decision variables}

$x_{n i k}$ : Quantity of merchandise $k$ to be loaded on vehicle $i$ in Stage (n). 
ISSN: 2236-269X

DOI: 10.14807/ijmp.v11i6.1209

$x_{n i j k}$ : Quantity of merchandise $k$ to be transported on the vehicle $i$ to unload at destination $j$ in Stage (n).

$b_{n i j}$ : Binary variables that model whether or not the destination $j$ is visited by the vehicle $i(0=$ not visited; $1=$ visited $)$ in Stage $(\mathrm{n})$

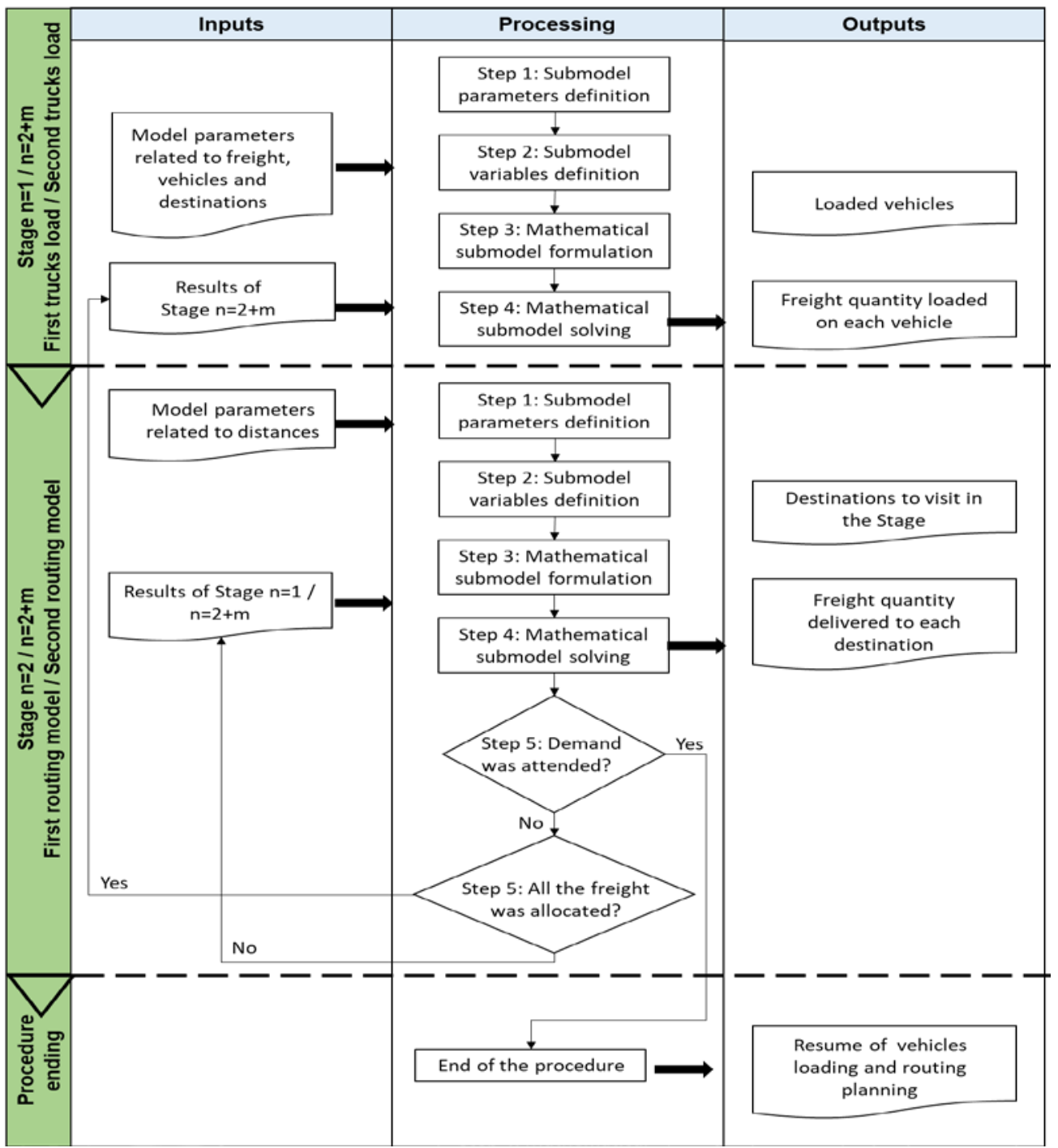

Figure 1: Model and procedure stages for freight planning and vehicular routing

Planning of the first freight load on the vehicles (submodel of multiobjective programming by-goals) - Stage $(n=1)$

Taking into account the characteristics of this first problem based on the structure given by which the model is decomposed, this sub-model makes use of the standard formulation of multi-objective programming by goals. The strict total demand fulfillment of the destinations for each merchandise to be loaded on the vehicles constitutes the modeled goals. This is because differentiating cost or performance criteria between vehicles are not available. 
DOI: 10.14807/ijmp.v11i6.1209

\section{Step 1. Definition of submodel parameters}

$I_{n=1, k}$ : Availability of merchandise $k$ in the warehouse (origin) in Stage ( $\left.\mathrm{n}=1\right)$.

$I_{n=1, k}=I_{k}, \forall k$;

$D_{n=1, j k}$ : Demand for merchandise $k$ at destination $j$ in Stage $(\mathrm{n}=1)$.

$D_{n=1, j k}=D_{j k}, \forall j$ and $\forall k$;

$c_{i k}$ : Capacity coefficient of the merchandise $k$ in the vehicle $i$ regardless of the Stage in which it is located.

\section{Step 2. Definition of submodel variables}

$x_{n=1, i k}$ : Decision variables that reflect the quantity of merchandise $k$ to be loaded on the vehicle $i$ in Stage $(n=1)$.

$y_{n=1, k}^{-}$: Underachievement variables or negative deviation that expresses the breach of the goals regarding the demand of the merchandise $k$ in the destinations determined for the Stage $(n=1)$.

$y_{n=1, k}^{+}$: Overachievement variables or positive deviation that expresses the overcompliance of the goals regarding the demand of the merchandise $k$ in the destinations determined for the Stage $(n=1)$.

\section{Step 3. Formulation of the mathematical submodel}

$$
\begin{array}{ll}
\text { OF: } & \text { MinZ }=\sum_{k=1}^{K}\left(y_{n k}^{+}+y_{n k}^{-}\right) \\
\text {s.a: } & \sum_{i=1}^{I} x_{n i k} \leq I_{n k} \forall \mathrm{k} \\
& \sum_{k=1}^{K} \frac{x_{n i k}}{c_{i k}} \leq 1 \forall \mathrm{i} \\
& \sum_{i=1}^{I} x_{n i k}+y_{n k}^{-}-y_{n k}^{+}=\sum_{j=1}^{J} D_{n j k} \forall \mathrm{k} \\
& x_{n i k} \geq 0 ; y_{n k}^{-} \geq 0 ; y_{n k}^{+} \geq 0
\end{array}
$$

The objective function (OF) represented by Eq. 3 minimizes positive and negative deviations, which will result in strict demand satisfaction. Eq. 4 models the restrictions that guarantee in order to load any quantity of merchandise into vehicles it must be available in the warehouse. The restriction formulated in Eq. 5 expresses that vehicles cannot be loaded over its capacity. These restrictions will depend on the volumetric capacity of the vehicles and the freight dimensions. Eq. 6 constitutes the goal, modeling the possible deviations of the freight 
DOI: 10.14807/ijmp.v11i6.1209

volume on vehicles regarding the total demand. Eq. 7 express the restrictions of non-negativity of both the decision variables and the variables of underachievement and overachievement of the goals.

\section{Step 4. Resolution of the mathematical submodel}

The formulated mathematical model is solved.

Programming of first visit of vehicles to destinations for freight distribution (mixed binary quadratic programming submodel) - Stage $(n=2)$

In this stage, the first visit of vehicles fleet to the destinations is scheduled as part of the routing to distribute the previously loaded freight. This link between Stages already raised previously, favors that the results of the previous Stage constitute parameters of the present.

\section{Step 1. Definition of submodel parameters}

$D_{n=2, j k}$ : Demand for merchandise $k$ at destination $j$ in Stage $(\mathrm{n}=2)$.

$D_{n=2, j k}=D_{j k}, \forall j$ and $\forall k$; Demand for merchandise $k$ at destination $j$ in Stage (n=2) is the same that the demand at the beginning of the problem

$x_{n=2, i k}$ : Quantity of the merchandise $k$ planned to be loaded in the vehicle $i$ in Stage $(\mathrm{n}=2)$.

$x_{n=2, i k}=x_{n=1, i k}, \forall j$ and $\forall k$; Quantity of merchandise $k$ planned to be loaded on vehicle $i$ in Stage $(\mathrm{n}=2)$ is the same that the quantity at the beginning of the problem

$$
p_{i_{n=2}}=0
$$

$d_{p_{i_{n=2}=0, p_{j}}}$ : Distance traveled by the vehicle $i$ from the physical position of the Warehouse $(\mathrm{p}=0)$ to destination $j$.

\section{Step 2. Definition of submodel decision variables}

$x_{n=2, i j k}$ : Quantity of merchandise $k$ to be transported in the vehicle $i$ for unloading at destination $j$ in the Stage $(\mathrm{n}=2)$.

$b_{n=2, i j}$ : Binary variables that model whether it is decided to visit or not the destination $j$ by the vehicle $i(0=$ if not visited; $1=$ if visited $)$ in Stage $(\mathrm{n}=2)$.

\section{Step 3. Formulation of the mathematical submodel}


DOI: 10.14807/ijmp.v11i6.1209

$$
\begin{gathered}
\text { OF: } \operatorname{MaxZ}=\sum_{i=1}^{I} \sum_{j=1}^{J} \sum_{k=1}^{K}\left(\frac{b_{n i j} * x_{n i j k} * w_{k}}{d_{p_{i_{n}} p_{j}}}\right) \\
\text { s.a: } \sum_{i=1}^{I} x_{n i j k} \leq D_{n j k} \forall \mathrm{j}, \forall \mathrm{k} \\
\sum_{j=1}^{J} x_{n i j k} \leq x_{n i k} \forall \mathrm{i}, \forall \mathrm{k} \\
\sum_{j=1}^{J} b_{n i j}=1 \forall i \\
x_{n i j k} \geq 0 \\
b_{n i j}\left\{\begin{array}{l}
b=1 \\
b=0
\end{array}\right.
\end{gathered}
$$

The OF in Eq. 10, links the binary variables with the quantity of merchandise to be unloaded on a destination in a directly proportional way, and inversely proportional with the distance that it is from the origin, which means that it is sought to maximize freight traffic generated by the routing process. The absence of relevant information to apply reliable criteria in terms of economics, such as, transportation costs, has an alternative by using the traffic load indicator compared to not presenting any.

The restrictions represented by Eq. 11 aims to not exceeding the demand for each merchandise in each destination. Eq. 12 models the restrictions implying that in each destination, a quantity of the merchandise is unloaded from each vehicle being less than or equal to the available by the vehicle capacity. Eq. 13 is responsible for modeling that each vehicle can only visit one destination, as defined by the Stage. The Eq. 14 represent the decision variables constraint of non-negativity, and the Eq. 15 the binary constraint for the other variables.

\section{Step 4. Resolution of the mathematical submodel}

The formulated mathematical model is solved.

\section{Step 5. Transition algorithm between Stages}

To determine the transition between submodels within the stages of the global mathematical model, the following Algorithm 1 (pseudocodes) is followed.

Algorithm 1: Determine the transition between stages

If $\sum_{n=1}^{1+m} \sum_{i=1}^{I} \sum_{j=1}^{J} \sum_{k=1}^{K} x_{n i j k}<\sum_{j=1}^{J} \sum_{k=1}^{K} D_{j k}$, then

//// It implies that the entire volume of merchandise distributed by the vehicles up to the stage $(\mathrm{n}=1+\mathrm{m})$ has not completed the demand for all destinations, therefore the distribution must continue.

If $\sum_{n=2}^{1+m} \sum_{i=1}^{I} \sum_{j=1}^{J} \sum_{k=1}^{K} x_{n i j k}<\sum_{i=1}^{I} \sum_{k=1}^{K} x_{n=1+m, i k}$, then 
ISSN: 2236-269X

DOI: 10.14807/ijmp.v11i6.1209

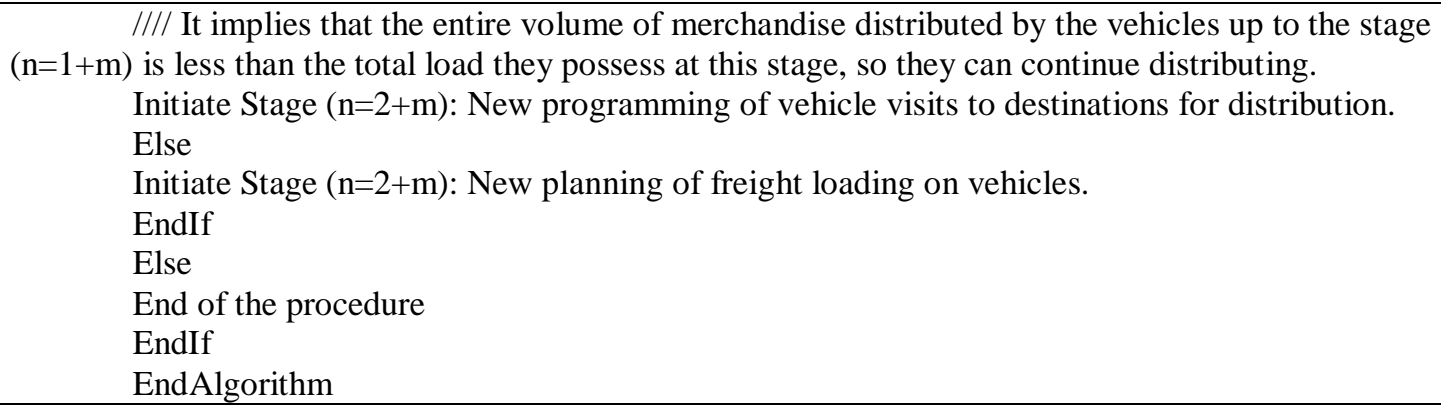

Regarding the transition algorithm between Stages that is applied, each Stage $(n=2+m)$ can generate two types of submodels until the solution for general mathematical model is obtained. In this case, $m$ is a positive integer variable beginning in one (1) that indicate the subsequent stages after the first two stages of loading and routing. These stages are explained below.

\section{New planning of the freight load on vehicles (sub-model of multi-objective programming by-goals) - Stage $(n=2+m)$}

\section{Step 1. Definition of submodel parameters}

$I_{n=2+m, k}$ : Availability of merchandise $k$ in the warehouse (origin) in Stage $(\mathrm{n}=2+\mathrm{m})$.

$I_{n=2+m, k}=I_{k}-\sum_{n=2}^{1+m} \sum_{i=1}^{I} \sum_{j=1}^{J} x_{n i j k} \quad \forall k$ : Availability of merchandise $k$ at the warehouse (origin) in Stage $(n=2+m)$ that is equal to the availability at the beginning of the problem minus the sum of all deliveries of merchandise $k$ in previous stages

$D_{n=2+m, j k}$ : Demand for merchandise $k$ at destination $j$ in Stage $(\mathrm{n}=2+\mathrm{m})$.

$D_{n=2+m, j k}=D_{j k}-\sum_{n=2}^{1+m} \sum_{i=1}^{I} x_{n i j k} \quad \forall j y \forall k$ : Demand for merchandise $k$ at destination $j$ in Stage $(\mathrm{n}=2+\mathrm{m})$ that is equal to the demand at the beginning of the problem minus the sum of all deliveries of merchandise $k$ at destination $j$ in previous stages

$c_{i k}$ : Capacity coefficient of the merchandise $k$ in the vehicle $i$ regardless of the stage in which it is located.

\section{Step 2. Definition of submodel variables}

$x_{n=2+m, i k}$ : Decision variables that reflect the quantity of merchandise $k$ to be loaded on the vehicle $i$ in Stage $(n=2+m)$.

$y_{n=2+m, k}^{-}:$Underachievement variables or negative deviation that expresses the nonfulfillment of the goals regarding the demand determined for the Stage $(n=2+m)$. 
DOI: 10.14807/ijmp.v11i6.1209

$y_{n=2+m, k}^{+}$: Overachievement variables or positive deviation expressing the overcompliance of the goals regarding the demand determined for the Stage $(n=2+m)$.

\section{Step 3. Formulation of the mathematical submodel}

The sub-model of multi-objective programming by-goals is formulated according to the Eq. 3 to 7 for this stage.

\section{Step 4. Resolution of the mathematical submodel}

The formulated mathematical model is solved.

New programming of vehicle visits to destinations for distribution (mixed binary quadratic programming submodel) - Stage $(n=2+m)$

\section{Step 1. Definition of submodel parameters}

$D_{n=2+m, j k}$ : Demand for merchandise $k$ at destination $j$ in Stage $(\mathrm{n}=2+\mathrm{m})$.

$D_{n=2+m, j k}=D_{j k}-\sum_{n=2}^{1+m} \sum_{i=1}^{I} x_{n i j k} \quad \forall j$ and $\forall k$ : Demand for merchandise $k$ at destination $j$ in Stage $(\mathrm{n}=2+\mathrm{m})$ that is equal to the demand at the beginning of the problem minus the sum of all deliveries of merchandise $k$ at the destination $j$ in previous stages

$x_{n=2+m, i k}$ : Quantity of merchandise $k$ loaded on the vehicle $i$ for distribution in Stage $(n=2+m)$.

$x_{n=2+m, i k}=x_{n=1+m, i k}-\sum_{j=1}^{J} x_{n=1+m, i j k,} \forall i$ and $\forall k$ : Quantity of merchandise $k$ loaded on vehicle $i$ for distribution in Stage $(n=2+m)$ that is equal to the demand at the beginning of the problem minus the sum of all deliveries of merchandise $k$ in previous stages (19)

$\mathrm{P}_{\mathrm{i}_{\mathrm{n}=2+\mathrm{m}}}$ : Physical position of vehicle $i$ in Stage $(\mathrm{n}=2+\mathrm{m})$. The Algorithm 2 (pseudocode) is used for its determination.

Algorithm 2: Determine the physical position of each vehicle in Stage $(2+m)$ : New programming of vehicle visits to destinations for freight distribution.

IIIIIIII/ Performed for each vehicle "i” at this stage and for each destination "j" at a previous stage

If Stage $(1+m)=$ "Schedule of vehicles visit to destinations for distribution", then

/II/ It implies that in the previous stage the transportation of goods was programmed

Consult $b_{n=1+m i j}$

//// denotes whether the vehicle "i” was assigned or not to transport goods to destination " $\mathrm{j}$ " in the previous stage

If $b_{n=1+m, i j}=1$, then

$$
\mathrm{P}_{\mathrm{i}_{\mathrm{n}}=2+\mathrm{m}}=\mathrm{j}
$$


ISSN: 2236-269X

DOI: 10.14807/ijmp.v11i6.1209

/II/ It implies that the vehicle "i" is at the beginning of the current stage on the position of the destination “j” that was assigned to transport goods in the previous stage]

Else

$\mathrm{P}_{\mathrm{i}_{\mathrm{n}=2+\mathrm{m}}}=$ Nulo

EndIf

Else

$$
\mathrm{p}_{\mathrm{i}_{\mathrm{n}=2+\mathrm{m}}}=0
$$

//// It implies that the vehicle returns to the origin to be loaded EndAlgorithm

$d_{p_{i_{n=2+m}}, p_{j}}$ : Distance to be traveled by the vehicle $i$ from its physical position in this stage to the destination $j$.

\section{Step 2. Definition of submodel variables}

$x_{n=2+m, i j k}$ : Decision variable that reflects the quantity of the merchandise $k$ to be transported on the vehicle $i$ for unloading at destination $j$ in the Stage $(n=2+m)$.

$b_{n=2+m, i j}$ : Binary variable that models whether or not to visit the destination $j$ by the vehicle $i(0=$ if not visited; $1=$ if visited $)$ in Stage $(n=2+m)$.

\section{Step 3. Formulation of the mathematical submodel}

The mixed binary quadratic programming submodel is formulated according to Eq. (10) to (15), for the present stage.

\section{Step 4. Resolution of the mathematical submodel}

The formulated mathematical model is solved.

\section{Step 5. Transition algorithm between Stages}

Proceed as indicated in Algorithm 1.

\section{Stage III. Model solution and validation. Case study results}

The feasibility of the proposed model is evaluated through a case study based on a real situation on the planning of raw material distribution in a Cuban tobacco company.

It is needed to transport four kinds of raw materials to four destinations (Production and Exportation facilities). The demand of each facilities (Destination 1, 2, 3 and Exportation 4), for a period, is known as presented in Table 1.

Table 1: Demand for raw material in destinations

\begin{tabular}{|r|c|c|c|c|}
\cline { 2 - 5 } \multicolumn{1}{c|}{ Freight (k) } & \multicolumn{4}{|c|}{ Demand $\left(D_{j k}\right)$} \\
\hline Destination (j) & Raw material 1 & $\begin{array}{c}\text { Raw material 2 } \\
\text { (Geaves) }\end{array}$ & $\begin{array}{c}\text { Raw material 3 } \\
\text { (Cloak) }\end{array}$ & $\begin{array}{c}\text { Raw material 4 } \\
\text { (Cape) }\end{array}$ \\
\hline Destination 1 & 17 boxes & 8 bales & 11 bales & 16 boxes \\
\hline
\end{tabular}


INDEPENDENT JOURNAL OF MANAGEMENT \& PRODUCTION (IJM\&P)

http://www.ijmp.jor.br

v. 11, n. 6, September - October 2020

ISSN: 2236-269X

DOI: 10.14807/ijmp.v11i6.1209

\begin{tabular}{|c|c|c|c|c|}
\hline Destination 2 & 16 boxes & 8 bales & 11 bales & 15 boxes \\
\hline Destination 3 & 11 boxes & 5 bales & 7 bales & 11 boxes \\
\hline Exportation 4 & 2 boxes & 1 bale & 1 bale & 2 boxes \\
\hline Total demand & 46 boxes & 22 bales & 30 bales & 44 boxes \\
\hline
\end{tabular}

The distribution is carried out from the raw material warehouse (Origin), where there is a certain availability of the merchandise to be distributed. Each raw material has a known unit weight according to their packaging as presented in Table 2.

Table 2: Availability of goods in the warehouse and their unit mass

\begin{tabular}{|c|c|c|}
\hline Freight $(\boldsymbol{k})$ & Availability in Warehouse $\left(I_{k}\right)$ & Unit weight $\left(w_{k}\right)$ \\
\hline Raw material 1 (Gut) & 123 boxes & $25 \mathrm{~kg} / \mathrm{box}$ \\
\hline Raw material 2 (Leaves) & 130 bales & $26,68 \mathrm{~kg} / \mathrm{bale}$ \\
\hline Raw material 3 (Cloak) & 125 bales & $25 \mathrm{~kg} / \mathrm{bale}$ \\
\hline Raw material 4 (Cape) & 121 bales & $21 \mathrm{~kg} / \mathrm{box}$ \\
\hline
\end{tabular}

Table 3 shows the load capacity of three vehicles that are available for transportation. Only the volumetric capacity is taken into account depending on the packaging of the merchandise to be loaded, since all products are classified as light according to their consistency.

Table 3: Volumetric and load capacity of vehicles

\begin{tabular}{|c|c|c|c|c|c|}
\hline \multirow{2}{*}{ Vehicle (i) } & \multirow{2}{*}{$\begin{array}{l}\text { Volumetric } \\
\text { capacity }\left(\mathrm{m}^{3}\right)\end{array}$} & \multicolumn{4}{|c|}{$\begin{array}{l}\text { Volumetric capacity depending on the merchandise to be loaded } \\
\qquad\left(c_{i k}\right)\end{array}$} \\
\hline & & $\begin{array}{l}\text { Raw material } \\
1 \text { (Gut) }\end{array}$ & $\begin{array}{l}\text { Raw material } \\
2 \text { (Leaves) }\end{array}$ & $\begin{array}{c}\text { Raw material } 3 \\
\text { (Cloak) }\end{array}$ & $\begin{array}{l}\text { Raw material } 4 \\
\text { (Cape) }\end{array}$ \\
\hline Truck Kamaz & $24 \mathrm{~m}^{3}$ & 95 boxes & 131 bales & 115 bales & 83 boxes \\
\hline Truck Howo & $20 \mathrm{~m}^{3}$ & 75 boxes & 109 bales & 96 bales & 69 boxes \\
\hline Truck KingLion & $10 \mathrm{~m}^{3}$ & 39 boxes & 54 bales & 48 bales & 34 boxes \\
\hline
\end{tabular}

Table 4 shows the travel distances to distribute the freight, from the origin to destinations, as well as the distances between destinations.

Table 4: Matrix of distances

\begin{tabular}{|l|c|c|c|c|}
\hline \multicolumn{5}{|c|}{ Distances to be traveled by vehicles between physical positions $\left(d_{i p j}\right)$} \\
\hline \multicolumn{1}{|c|}{ Destinations $(j)$} & Destination 1 & Destination 2 & Destination 3 & Exportation 4 \\
Physical position $(p)$ & & & & $4.1 \mathrm{~km}$ \\
\hline Origin (Warehouse) & $34.5 \mathrm{~km}$ & $51.6 \mathrm{~km}$ & $34.1 \mathrm{~km}$ & $33.8 \mathrm{~km}$ \\
\hline Destination 1 & - & $20.8 \mathrm{~km}$ & $51.2 \mathrm{~km}$ & $52.8 \mathrm{~km}$ \\
\hline Destination 2 & $20.8 \mathrm{~km}$ & - & - & $11.5 \mathrm{~km}$ \\
\hline Destination 3 & $34.1 \mathrm{~km}$ & $51.2 \mathrm{~km}$ & $11.5 \mathrm{~km}$ & - \\
\hline Exportation facility 4 & $33.8 \mathrm{~km}$ & $52.8 \mathrm{~km}$ & \\
\hline
\end{tabular}

The generic VRP treated in the literature are classified in NP-hard, so issues concerning to the type of software and hardware used to solve them is very relevant due to the implications of the computational effort required. The solution to the problem studied is simplified by means 
ISSN: 2236-269X

DOI: 10.14807/ijmp.v11i6.1209

of the application of a heuristic method, and it was possible to solve it using the WinQSB 2.0 software on a Corei5 PC with 4 GB of RAM memory in a relatively short time. From the application of the formulated mathematical model were obtained, with its solution procedure, the following results.

Table 5 presents the quantity of freight loaded out on the vehicles in a first stage. As shown (Table 5), was only needed to use two of the three vehicles available to fully satisfy the demand of the destinations, which implies that only one stage is necessary for planning the vehicle loading.

Table 5: First freight load to be transported - Stage $(n=1)$

\begin{tabular}{|c|c|c|c|c|}
\hline \multirow{2}{*}{ Vehicles } & \multicolumn{4}{|c|}{ Amount of freight to be loaded } \\
\cline { 2 - 5 } & $\begin{array}{c}\text { Raw material 1 } \\
\text { (Gut) }\end{array}$ & $\begin{array}{c}\text { Raw material 2 } \\
\text { (Leaves) }\end{array}$ & $\begin{array}{c}\text { Raw material 3 } \\
\text { (Cloak) }\end{array}$ & $\begin{array}{c}\text { Raw material 4 } \\
\text { (Cape) }\end{array}$ \\
\hline Kamaz & 46 boxes & 22 bales & 30 bales & 6 boxes \\
\hline Howo & - & - & - & 38 boxes \\
\hline
\end{tabular}

As shown in Table 6, the first trip of the loaded fleet is scheduled as part of the vehicle routing to distribute the freight. This allows meeting the demand of the Destination 1 , at the same time that it generates optimal traffic load for this Stage, starting from the Warehouse that constitutes the origin.

Table 6: First trip of freight distribution's routing - Stage $(n=2)$

\begin{tabular}{|c|c|c|c|c|}
\hline \multirow{3}{*}{ Vehicles } & \multicolumn{4}{|c|}{$\begin{array}{c}\text { Destination } 1 \\
\text { Traffic load generated: } 18.11 \mathrm{~kg} / \mathrm{km}\end{array}$} \\
\cline { 2 - 5 } & \multicolumn{4}{|c|}{ Amount of freight to be distributed } \\
\cline { 2 - 5 } & $\begin{array}{c}\text { Raw material 1 } \\
\text { (Gut) }\end{array}$ & $\begin{array}{c}\text { Raw material 2 } \\
\text { (Leaves) }\end{array}$ & $\begin{array}{c}\text { Raw material 3 } \\
\text { (Cloak) }\end{array}$ & $\begin{array}{c}\text { Raw material 4 } \\
\text { (Cape) }\end{array}$ \\
\hline Kamaz & 17 boxes & 8 bales & 11 bales & 4 boxes \\
\hline Howo & - & - & - & 12 boxes \\
\hline
\end{tabular}

The programming of the second trip of the loaded fleet is carried out in Stage 3, based on the fact that the vehicles have as initial physical position (Destination 1) and the freight's availability to be distributed has decreased due to the first delivery, but it is adjusted to the destinations demand. This satisfies the demand of Destination 2. Based on the conditions described above, optimal traffic load is obtained for this Stage, as shown in Table 7.

Table 7. Second trip for freight distribution's routing - Stage $(n=3)$

\begin{tabular}{|c|c|c|c|c|}
\hline \multicolumn{5}{|c|}{$\begin{array}{c}\text { Destination visited: Destination } 2 \\
\text { Traffic load generated: 28.92 kg/km }\end{array}$} \\
\hline \multirow{3}{*}{ Vehicles } & \multicolumn{4}{|c|}{ Amount of freight to be distributed } \\
\cline { 2 - 5 } & $\begin{array}{c}\text { Raw material 1 } \\
\text { (Gut) }\end{array}$ & $\begin{array}{c}\text { Raw material 2 } \\
\text { (Leaves) }\end{array}$ & $\begin{array}{c}\text { Raw material 3 } \\
\text { (Cloak) }\end{array}$ & $\begin{array}{c}\text { Raw material 4 } \\
\text { (Cape) }\end{array}$ \\
\hline Kamaz & 16 boxes & 8 bales & 11 bales & - \\
\hline Howo & - & - & - & 15 boxes \\
\hline
\end{tabular}


DOI: 10.14807/ijmp.v11i6.1209

The third trip of the fleet is scheduled in Stage 4, having as initial physical position (Origin) for both vehicles the Destination 2 already visited, with the freight's availability to be distributed adjusted according to the deliveries already made. The destination that is obtained to be visited is Destination 3 in order to meet its demand and an optimal traffic load value for the conditions of this stage is obtained. The results are shown in Table 8.

Table 8: Third trip for freight distribution's routing - Stage $(n=4)$

\begin{tabular}{|c|c|c|c|c|}
\hline \multicolumn{5}{|c|}{$\begin{array}{c}\text { Destination visited: Destination } 3 \\
\text { Traffic load generated: } 7.95 \mathrm{~kg} / \mathrm{km}\end{array}$} \\
\hline \multirow{3}{*}{ Vehicles } & \multicolumn{5}{|c|}{ Amount of freight to be distributed } \\
\cline { 2 - 6 } & $\begin{array}{c}\text { Raw material 1 } \\
\text { (Gut) }\end{array}$ & $\begin{array}{c}\text { Raw material 2 } \\
\text { (Leaves) }\end{array}$ & $\begin{array}{c}\text { Raw material 3 } \\
\text { (Cloak) }\end{array}$ & $\begin{array}{c}\text { Raw material 4 } \\
\text { (Cape) }\end{array}$ \\
\hline Kamaz & 11 boxes & 5 bales & 7 bales & - \\
\hline Howo & - & - & - & 11 boxes \\
\hline
\end{tabular}

In Stage 5, the visit to the last destination (Exportation facility) is scheduled, satisfying its demand. Only a vehicle is used as shown in Table 9. This concludes the procedure according to that is established in the algorithm.

Table 9: Four trip for freight distribution's routing - Stage $(n=5)$

\begin{tabular}{|c|c|c|c|c|}
\hline \multicolumn{5}{|c|}{$\begin{array}{l}\text { Destination visited: Exportation facility } \\
\text { Traffic load generated: } 12.49 \mathrm{~kg} / \mathrm{km}\end{array}$} \\
\hline \multirow[b]{2}{*}{ Vehicles } & \multicolumn{4}{|c|}{ Amount of freight to be distributed } \\
\hline & $\begin{array}{c}\text { Raw material } 1 \\
\text { (Gut) }\end{array}$ & $\begin{array}{c}\text { Raw material } 2 \\
\text { (Leaves) }\end{array}$ & $\begin{array}{c}\text { Raw material } 3 \\
\text { (Cloak) }\end{array}$ & $\begin{array}{c}\text { Raw material } 4 \\
\text { (Cape) }\end{array}$ \\
\hline Kamaz & 2 boxes & 1 bale & 1 bale & 2 boxes \\
\hline
\end{tabular}

The mathematical model configured for vehicle loading and routing is viable for the company studied. The model allowed the scheduling of vehicles load and routing for a specific case study (Tobacco Company) based on the reality of its operational management. This model responds in its configuration to a heuristic method. This method is also known as tailored algorithms, not being usable for others problems (TELFAR, 1994).

With this model, a local optimum of the problem studied is defined at each stage in which it is segmented. However, the solution obtained does not guarantee the global optimum given the "myopia" of the proposed procedure, which does not follow the principle of optimality typical of dynamic programming that states that an optimal policy for the remaining stages is independent of the policy adopted in previous stages (DELGADO et al., 2015).

The technique used avoids exploring all possible sequences by solving the subproblems to facilitate the solution of the biggest one. This procedure is justified based on the cost in time and other computational resources that would imply developing a procedure to find an optimal solution that, on the other hand, given the case studied in this paper, will not represent an important benefit. 
DOI: 10.14807/ijmp.v11i6.1209

The formulated model used as an operational procedure for loading and vehicular routing for distribution of raw materials in the tobacco company (case study) has the potential to contribute for achieving a more rational use of the available fleet. In the case study analyzed in this paper, only two of the three vehicles available were used for distributing the freight, and in the last stage, only one of them was needed. Likewise, the value of the total traffic load indicator, obtained for vehicular routing is $5.27 \mathrm{~kg} / \mathrm{km}$ traveled, while they oscillate between $2.75 \mathrm{~kg} / \mathrm{km}$ and $10 \mathrm{~kg} / \mathrm{km}$ at each stage. These values are higher than the average values that were reported by these vehicles monthly, ranging between $1.27 \mathrm{~kg} / \mathrm{km}$ and $1.59 \mathrm{~kg} / \mathrm{km}$.

\section{FINAL REMARKS}

An integrated heuristic mathematical model for freight loading and vehicle routing was configured in this paper. The model was applied for evaluate the characteristics of the physical distribution of raw materials process and its feasibility was evaluated through a case study based on a real and timely problem situation in a Cuban tobacco company concluding the following:

a) The four stages developed and applied in the case study presented high reliability on the study of a real problem;

b) The model results allowed scheduling the freight loading and the vehicular routing with reliable performance;

c) The heuristic method used is an interesting alternative to solve complex load and vehicle routing problems, even if it does not involve reaching the optimal solution;

d) The proposed mathematical model, as part of the operational management of the merchandise distribution in the company studied represents an opportunity for production processes improvement;

e) Despite dealing with complex integrated problems, the proposed method is simple and easy to implement and replicate in others manufacturing companies.

\section{REFERENCES}

ADAMS, W.; WADDELL, L. (2014) Linear programming insights into solvable cases of the quadratic assignment problem. Discrete Optimization, v. 14, p. 46-60. http://doi.org/10.1016/j.disopt.2014.07.001

AQUINO, W. J. S. (1980) Uma abordagem do problema de definição de rede

interurbana de rotas de ônibus. Dissertação em opção ao título de mestre em Engenharia de Produção. Coordenação do Programa de Pós-Graduação de Engenharia. Universidade Federal do Rio de Janeiro, Rio de Janeiro, Outubro, p.1-88. 
DOI: 10.14807/ijmp.v11i6.1209

BORTFELDT, A.; WÄSCHER, G. (2013) Constraints in container loading-A state-of-the-art review. European Journal of Operational Research, v. 229, n. 1, p. 1-20.

http://doi.org/10.1016/j.ejor.2012.12.006

\section{BURKARD, R.; DELL'AMICO, M.; MARTELLO, S. (2012|) Assignment problems}

(Revised reprint). SIAM - Society of Industrial and Applied Mathematics, 393 p., ISBN 9781-611972-22-1.

CHOKANAT, P.; PITAKASO, R.; SETHANAN, K. (2019) Methodology to Solve a Special Case of the Vehicle Routing Problem: A Case Study in the Raw Milk Transportation System. AgriEngineering, v. 1, n. 1, p. 75-93. http://doi.org/10.3390/agriengineering1010006

CHOWMALI, W.; SUKTO, S. (2020) A novel two-phase approach for solving the multicompartment vehicle routing problem with a heterogeneous fleet of vehicles: a case study on fuel delivery. Decision Science Letters, v. 9, n. 1, p. 77-90.

http://doi.org/10.5267/j.dsl.2019.7.003

CORSTJENS, J.; DEPAIRE, B.; CARIS, A.; SORENSEN, K. (2019) A multilevel evaluation method for heuristics with an application to the VRPTW. International Transactions in Operational Research, v. 27, p. 168-196. http://doi.org/10.1111/itor.12631

DANTZIG, G. B.; FULKERSON, D. R.; JOHNSON, S. M. (1954) Solution of a Large-Scale Traveling Salesman Problem. Operations Research, n. 2, p. 393-410. http://doi.org/10.1287/opre.2.4.393

DELGADO, J. A. C.; AVALOS, L. C. M.; DELGADO, E. R.; PUYCÁN, L. A. L. (2015) Optimización de programas matemáticos con programación dinámica. Revista Ciencia \& Desarrollo, n. 19, p. 77-83. http://doi.org/10.33326/26176033.2015.19.491

DUHAMEL, C.; LACOMME, P.; QUILLIOT, A.; TOUSSAINT, H. (2010) A multi-start evolutionary local search for the two-dimensional loading capacitated vehicle routing problem. Computers \& Operations Research, v. 38, n. 3, p. 617-640.

http://doi.org/10.1016/j.cor.2010.08.017

FUELLERER, G.; DOERNER, K. F.; HARTL, R. F.; IORI, M. (2009) Ant colony optimization for the two-dimensional loading vehicle routing problem. Computers \& Operations Research, v. 36, n. 3, p. 655-673. http://doi.org/10.1016/j.cor.2007.10.021

HILLIER, F. S.; LIEBERMAN, G. J. (2004) Introduction to Operations Research. Ed. 8, McGraw-Hill, p. 1088. ISBN 0-07-252744-7

IORI, M.; MARTELLO, S. (2016) An annotated bibliography of combined routing and loading problems. Yugoslav Journal of Operations Research, v. 23, n. 3, p. 311-326. http://doi.org/10.2298/YJOR130315032I

LAURENT, M.; SEMINAROTI, M. (2015) The quadratic assignment problem is easy for Robinsonian matrices with Toeplitz structure. Operations Research Letters, v. 43, n. 1, p. 103-109. http://doi.org/10.1016/j.orl.2014.12.009

LÜER, A.; BENAVENTE, M.; BUSTOS, J.; VENEGAS, B. (2009) El problema de rutas de vehículos: extensiones y métodos de resolución, estado del arte. Proceedings of $3^{\text {er }}$

Encuentro de Informática y Gestión (EIG 2009), Universidad de la Frontera, Temuco, Chile. Available at: http://www.semanticscholar.org/paper/El-Problema-de-Rutas-de-

Veh\%C3\%ADculos\%3A-Extensiones-y-de-L\%C3\%BCer-

Benavente/e47e71d4f7470d69dd987190286cfd48eeabae61 
MASTRAPA, L. H. (2017) Melhorias em um método heurístico para a solução do Problema de Desenho de Rede de Transporte Público Urbano. Dissertação de MestradoDepartamento de Engenharia Industrial. Pontifícia Universidade Católica do Rio de Janeiro, Rio de Janeiro, Agosto, p. 1-114. https://doi.org/10.17771/PUCRio.acad.31654

MASTRAPA, L. H.; LEAL, J. E.; ASSUMPÇÃO, M. R. P. (2018b) Melhorias em um método heurístico para a solução do problema de desenho de rede de transporte público urbano. In: XXXVIII Encontro Nacional de Engenharia de Produção ENEGEP 2018, Maceió, Alagoas, Brasil. Available at: http://www.abepro.org.br/biblioteca/TN_WPG_263_509_36318.pdf

MASTRAPA, L. H.; VELÁZQUEZ, D. R. T.; OLIVEIRA, E. D.; GENNARO, C. K.; BELEM, M. J. X. (2018a) Análise dos modelos matemáticos para o transporte de ajuda humanitária em situações de desastres. In: VIII Congresso Brasileiro de Engenharia de Produção CONBREPRO 2018, Ponta Grossa, Paraná, Brasil. Available at: http://aprepro.org.br/conbrepro/2018/anais.php

MEDINA, L. B. R.; LA ROTTA, E. C. G.; CASTRO, J. A. O. (2011) Una revisión al estado del arte del problema de ruteo de vehículos: Evolución histórica y métodos de solución. Ingeniería, v. 16, n. 2, p. 35-55. Available at: http://dialnet.unirioja.es/servlet/articulo?codigo=4797255

NGUYEN, B.; MORELL, C.; DE BAETS, B. (2016) Un método eficiente para resolver un problema de programación cuadrática derivado del aprendizaje de funciones de distancia. Investigación Operacional, v. 37, n. 2, p. 124-136. Available at: http://go.gale.com/ps/anonymous?id=GALE\%7CA458262039\&sid=googleScholar\&v=2.1\&i $\mathrm{t}=\mathrm{r} \&$ linkaccess $=\mathrm{abs} \& \mathrm{issn}=02574306 \& \mathrm{p}=\mathrm{AONE} \& \mathrm{sw}=\mathrm{w}$

ONEI - Oficina Nacional de Estadística e Información (2015) Anuario Estadístico de Cuba. La Habana, Cuba, Edición 2016.

ORTIZ-TRIANA, V. K.; CAICEDO-ROLÓN, Á. J. (2014) Programación óptima de la producción en una pequeña empresa de calzado - en Colombia. Ingeniería Industrial, v. 35, n. 2, p. 114-130. Available at: http://scielo.sld.cu/scielo.php?script=sci_arttext\&pid=S181559362014000200002

PACE, S.; TURKY, A.; MOSER, I.; ALETI, A. (2015) Distributing fibre boards: a practical application of the heterogeneous fleet vehicle routing problem with time windows and threedimensional loading constraints. Procedia Computer Science, v. 51, p. 2257-2266.

http://doi.org/10.1016/j.procs.2015.05.382

PIQUERAS, V. Y. (2002) Optimización heurística económica aplicada a las redes de transporte del tipo VRPTW. [Doctoral Thesis, p. 351], Universidad Politécnica de Valencia, 2002. http://doi.org/10.4995/Thesis/10251/2664

SMITI, M.; DHIAF, M. M.; JARBOUI, B.; HANAFI, S. (2020). Skewed general variable neighborhood search for the cumulative capacitated vehicle routing problem. International Transactions in Operational Research, n. 27, p. 651-664. http://doi.org/10.1111/itor.12513

TARANTILIS, C. D.; ZACHARIADIS, E. E.; KIRANOUDIS, C. T. (2009) A hybrid metaheuristic algorithm for the integrated vehicle routing and three-dimensional containerloading problem. IEEE Transactions on Intelligent Transportation Systems, v. 10, n. 2, p. 255-271. http://doi.org/10.1109/TITS.2009.2020187

TELFAR, G. (1994) Generally Applicable Heuristics for Global Optimization: An Investigation of Algorithm Performance for the Euclidean Traveling Salesman Problem. 
ISSN: 2236-269X

DOI: 10.14807/ijmp.v11i6.1209

Reading paper - Master of Science in Statistics and Operations Research, p. 150, Victoria University of Wellington.

WICHAPA, N.; KHOKHAJAIKIAT, P. (2018) Solving a multi-objective location routing problem for infectious waste disposal using hybrid goal programming and hybrid genetic algorithm. International Journal of Industrial Engineering Computations, v. 9, n. 1, p. 75-98. http://doi.org/10.5267/j.ijiec.2017.4.003 